\title{
Occurrence of phytophagous thrips (Thysanoptera) and harmfulness of Thrips tabaci Lind. in carrot (Daucus carota L. ssp. sativus) cultivation
}

\author{
Występowanie roślinożernych wciornastków (Thysanoptera) \\ oraz szkodliwość Thrips tabaci Lind. \\ w uprawie marchwi jadalnej (Daucus carota L. ssp. sativus)
}

\author{
Irena Łuczak ${ }^{1}$, Małgorzata Gaborska ${ }^{1}$, Maria Pobożniak $^{1}$, Adam Świderski $^{2}$, Michał Kruczek ${ }^{2}$
}

\begin{abstract}
Summary
The density of thrips (Thysanoptera) population on ten hybrid cultivars of carrot was estimated in the field experiment in 2011-2012. The influence of Thrips tabaci Lind. feeding on yielding of carrot was studied in the insulator experiments. Changes in the content of soluble sugars, sucrose and total carotenoids in roots of plants infested by thrips in relation to the control plants were also determined. In both seasons the most numerous species of thrips was $T$. tabaci ( $47.7 \%$ of all caught thrips). The cultivar most often inhabited by thrips was Deep Purple $F_{1}$ - the carrot having a purple tinge of root and dark-green leaves. The feeding of thrips almost always causes a reduction in marketable yield of roots. However, the plants infested by $T$. tabaci were characterized by an increase of soluble sugars and sucrose content in roots. Decrease or increase in total carotenoids content in roots was depended on carrot cultivar.
\end{abstract}

Key words: thrips; carrot; cultivars; Thrips tabaci; harmfulness

\section{Streszczenie}

W doświadczeniu polowym przeprowadzonym w latach 2011-2012 oceniano liczebność populacji wciornastków (Thysanoptera) na 10 mieszańcowych odmianach marchwi jadalnej. W doświadczeniu izolatorowym badano wpływ żerowania Thrips tabaci Lind. na plonowanie marchwi. Określano także zmiany w zawartości cukrów rozpuszczalnych, sacharozy i sumy karotenoidów w korzeniach roślin zasiedlanych przez wciornastki w stosunku do roślin kontrolnych. W obu sezonach najliczniej występującym gatunkiem był T. tabaci, który stanowił $47,7 \%$ wszystkich odłowionych okazów wciornastków. Odmianą najliczniej zasiedlaną przez wciornastki była Deep Purple $\mathrm{F}_{1}$ - o fioletowym zabarwieniu korzeni i ciemnozielonych liściach. Żerowanie wciornastków wpływało prawie zawsze na obniżenie plonu handlowego korzeni. Jednakże u roślin zasiedlonych przez $T$. tabaci obserwowano wzrost zawartości cukrów rozpuszczalnych i sacharozy w korzeniach. Zależnie od odmiany marchwi zawartość karotenoidów w korzeniach ulegała zmniejszeniu lub zwiększeniu.

Słowa kluczowe: wciornastki; marchew; odmiany; Thrips tabaci; szkodliwość

Uniwersytet Rolniczy im. Hugona Kołłątaja w Krakowie

Al. 29 Listopada 54, 31-425 Kraków

${ }^{1}$ Katedra Ochrony Roślin

i.luczak@ogr.ur.krakow.pl; m.pobozniak@ogr.ur.krakow.pl

${ }^{2}$ Zakład Biochemii, Instytut Biologii Roślin i Biotechnologii 


\section{Wstęp / Introduction}

Wciornastki (Thysanoptera) są wszędobylskimi owadami, wśród których, liczną grupę stanowią gatunki fitofagiczne. Owady te są szkodnikami notowanymi często w uprawach ogrodniczych (Szwejda 2002). W literaturze przytaczane są wyniki badań omawiające żerowanie Thysanoptera w uprawie takich gatunków warzyw, jak: kapusta (Shelton i wsp. 1988; Legutowska 1997; Pobożniak i Wiech 2004; Pobożniak 2005), cebula (Richter i wsp. 1999), por (Legutowska i Kucharczyk 2000) i groch (Pobożniak 2009; Pobożniak i Gaborska 2010). Jak dotąd, nie przeprowadzono szczegółowych badań nad występowaniem i szkodliwością wciornastków na roślinach marchwi uprawnej.

Praca zawiera wyniki dwuletnich obserwacji polowych, w których określano liczebność i skład gatunkowy fitofagicznych Thysanoptera, zasiedlających wybrane mieszańcowe odmiany marchwi jadalnej. Przedstawiono wyniki doświadczenia izolatorowego, w którym oceniano wpływ żerowania dominującego gatunku wciornastka Thrips tabaci Lind., na plon handlowy oraz zawartość cukrów i karotenoidów w korzeniach marchwi.

\section{Materiały i metody / Materials and methods}

Badania prowadzono w latach 2011-2012 na poletkach Stacji Doświadczalnej w Mydlnikach, należącej do Uniwersytetu Rolniczego w Krakowie. Obserwacjami objęto 10 nowych mieszańcowych odmian marchwi, pochodzących z trzech hodowli: „Polan” (Rumba $\mathrm{F}_{1}$, Samba $\mathrm{F}_{1}$ ); „PlantiCo Gołębiew” (Afro $\mathrm{F}_{1}$, Kongo $\mathrm{F}_{1}$ ); „Bejo Zaden Poland” (Kazan $F_{1}$, Napa $F_{1}$, Nipomo $F_{1}$, Deep Purple $F_{1}$, Yellowstone $F_{1}$, White Satin $F_{1}$ ). Doświadczenie odmianowe (w obu sezonach wegetacyjnych) założono w układzie bloków losowanych w trzech powtórzeniach. Marchew była siana w drugiej dekadzie kwietnia na poletkach o powierzchni $10 \mathrm{~m}^{2}(4 \times 2,5 \mathrm{~m})$ każde. W sąsiedztwie poletek doświadczalnych były uprawiane takie rośliny, jak: cebula, groch, zioła oraz jednoroczne rośliny ozdobne.

Skład gatunkowy wciornastków określono na podstawie okazów postaci dorosłych odłowionych z marchwi za pomocą standardowego czerpaka entomologicznego. Odłowy czerpakowe wykonywano od początku czerwca do końca sierpnia. W 2011 roku wciornastki odławiano 3-krotnie, wykonując po jednym odłowie w czerwcu, lipcu i sierpniu; w 2012 roku Thysanoptera były odławiane 6-krotnie, tj. w dwutygodniowych odstępach czasu. Za jedną próbę przyjęto 25 zagarnięć standardowym czerpakiem entomologicznym z każdego poletka. Zebrany materiał analizowano i oznaczano w warunkach laboratoryjnych; liczono owady dorosłe i larwy Thysanoptera. Identyfikację taksonomiczną dokonano w oparciu o specjalistyczne klucze (Zawirska 1994; Strassen 2003).

Wpływ żerowania $T$. tabaci na plonowanie marchwi badano w 2012 roku w doświadczeniu poletkowym pod izolatorami. Dla każdej testowanej odmiany zastosowano dwa warianty: I - izolatory $\mathrm{z}$ naniesionymi na rośliny wciornastkami (W) oraz II - izolatory z roślinami kontrol- nymi (bez owadów - K). Każdy wariant obejmował 3 izolatory. Po wschodach marchwi, środkowe rzędy roślin na poletkach odmianowych nakrywano agrowłókniną. W połowie lipca (po zdjęciu agrowłókniny) na wybrane rośliny mocowane były metalowe konstrukcje (stelaże) i zakładane izolatory z gazy młyńskiej (o wysokości i średnicy $50 \mathrm{~cm}$ ). Dla każdej odmiany izolowano po 5 roślin w 6 miejscach; w wariancie I na izolowane rośliny nanoszone były osobniki dorosłe wciornastka tytoniowca w liczbie 10 osobników/izolator. W doświadczeniu wykorzystano samice T. tabaci; odłowiono je wcześniej z poletek odmianowych marchwi. Wciornastki żerowały przez okres 6 tygodni. Zbiór marchwi przeprowadzono w końcu sierpnia. Dla danego wariantu i odmiany określono liczbę i procent korzeni handlowych, zmierzono długość (w cm) i zważono masę ( $\left.\begin{array}{lll}\mathrm{w} & \mathrm{g}\end{array}\right)$ każdego pojedynczego korzenia. Następnie, w korzeniach marchwi (pochodzących z obu wariantów doświadczenia - K, W) oznaczono zawartość cukrów i karotenoidów. Cukry rozpuszczalne oznaczono metodą antronową (Samotus i wsp. 1993), natomiast cukry redukujące metodą cyjanożelazianową (Nath i Singh 1965). Zawartość karotenoidów oznaczono metodą spektrofotometryczną; otrzymaną sumę karotenoidów przeliczono na $\beta$-karoten uwzględniając jego współczynnik absorpcji równy 2450 przy $450 \mathrm{~nm}$ (Świderski i Kostecka-Gugała 2009).

\section{Wyniki i dyskusja / Results and discussion}

W obu sezonach wegetacyjnych na poletkach doświadczalnych z odmianami marchwi stwierdzono obecność 15 fitofagicznych gatunków Thysanoptera (tab. 1). Wśród odłowionych wciornastków zdecydowaną większość stanowiły osobniki dorosłe - 92,3\% (tab. 2). Najliczniej reprezentowanym gatunkiem był $T$. tabaci. Jego udział w zebranym materiale $\mathrm{z}$ marchwi był bardzo wysoki i wynosił $47,7 \%$ (tab. 1). Drugim pod względem liczebności okazał się T. fuscipennis Haliday - 23,7\% ogółu odłowionych owadów. Pomimo, iż gatunek ten związany jest z kwiatami, to przez niektórych autorów jest także wykazywany w materiale Thysanoptera, pozyskiwanym z liści. Pobożniak (2011) obserwowała dość liczne występowanie $T$. fuscipennis na warzywach $\mathrm{z}$ rodziny Fabaceae - przed kwitnieniem. Autorka wyjaśniła, że w tym okresie wciornastek ten mógł żerować tylko na liściach lub na pędach roślin. Alford (2002) opisuje jego żerowanie na młodych liściach róż. Nieliczne występowanie wciornastka różówka było obserwowane na porach (Legutowska i Theunissen 2003) oraz na kapuście (Legutowska 1997; Pobożniak 2005). Wykazana w pracy wysoka liczebność T. fuscipennis na marchwi mogła wynikać także z obecności kwitnących roślin ozdobnych (astry, nagietki), uprawianych w sąsiedztwie poletek doświadczalnych. Podobnie było $\mathrm{z}$ innymi gatunkami wciornastków: Frankliniella intonsa (Trybom), T. atratus Haliday, T. major Uzel, T. physaphus Linneus i T. validus Uzel, które troficznie związane są z kwiatami różnych roślin. Pozostałe stwierdzone gatunki to polifagi, związane z trawami; jedynie Odontothrips loti (Haliday) jest oligofagiem związanym z rodziną Fabaceae. Ich obecność na marchwi należy uznać za przypadkową. 
Larwy stanowiły jedynie $7,7 \%$ odłowionego materiału. Jednak sama ich obecność świadczy o tym, że marchew jest rośliną, na której wciornastki mogą żerować i rozwijać się (tab. 2).

W odniesieniu do testowanych odmian marchwi liczebności odłowionych wciornastków były różne. Najwięcej postaci dorosłych Thysanoptera - ogółem 138 sztuk (w tym trzech najliczniejszych gatunków: T. tabaci, T. fuscipennis i $F$. intonsa) odłowiono z roślin marchwi odmiany Deep Purple $F_{1}-o$ purpurowym zabarwieniu korzeni i ciemnym (przebarwiającym się na czerwono i fioletowo) listowiu (tab. 1). Łączna liczba odłowionych wciornastków (owady dorosłe) była najmniejsza (85 sztuk) na marchwi odmiany White Satin $F_{1}-o$ białych korzeniach i bladozielonym zabarwieniu liści. Na tych dwóch odmianach liczby larw Thysanoptera były zbliżone i wynosiły odpowiednio 12 oraz 11 sztuk (tab. 2).

Tabela 1. Występowanie roślinożernych gatunków wciornastków (Thysanoptera) na wybranych odmianach marchwi w latach 2011-2012

Table 1. Occurrence of phytophagous thrips species (Thysanoptera) on selected carrot cultivars in 2011-2012

\begin{tabular}{|c|c|c|c|c|c|c|c|c|c|c|c|c|}
\hline \multirow{3}{*}{$\begin{array}{l}\text { Gatunek } \\
\text { Species }\end{array}$} & \multicolumn{10}{|c|}{ Odmiana - Cultivar } & \multirow[b]{2}{*}{ 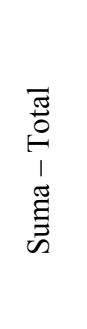 } & \multirow{2}{*}{ 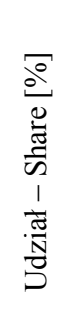 } \\
\hline & 㭊 &  &  & $\begin{array}{l}\overline{\mid} \\
0 \\
00 \\
\tilde{0} \\
\underline{0}\end{array}$ & $\begin{array}{l}\sqrt{\tilde{Z}} \\
\text { בै } \\
\text { Z }\end{array}$ & 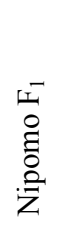 & $\begin{array}{l}\vec{I} \\
\overrightarrow{\tilde{E}} \\
\vec{E} \\
\overrightarrow{\tilde{D}}\end{array}$ & 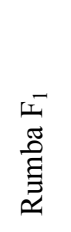 & 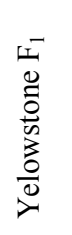 &  & & \\
\hline & \multicolumn{12}{|c|}{$\begin{array}{l}\text { łączna liczba wciornastków (owady dorosłe) } \\
\text { total number of thrips (adults) }\end{array}$} \\
\hline $\begin{array}{l}\text { Anaphothrips obscurus } \\
\text { (Müller 1776) }\end{array}$ & 10 & 6 & 8 & 4 & 14 & 5 & 11 & 10 & 6 & 6 & 80 & 7,0 \\
\hline $\begin{array}{l}\text { Chirothrips manicatus } \\
\text { Haliday } 1836\end{array}$ & 1 & 1 & 3 & 1 & 4 & 2 & 1 & 5 & 2 & 1 & 21 & 1,8 \\
\hline $\begin{array}{l}\text { Frankliniella intonsa } \\
\text { (Trybom 1895) }\end{array}$ & 12 & 12 & 7 & 9 & 6 & 8 & 8 & 12 & 11 & 2 & 87 & 7,6 \\
\hline $\begin{array}{l}\text { Haplothrips aculeatus } \\
\text { (Haliday 1803) }\end{array}$ & 6 & 5 & 4 & 1 & 3 & 3 & 7 & 2 & 6 & 2 & 39 & 3,4 \\
\hline $\begin{array}{l}\text { Limothrips denticornis } \\
\text { Haliday } 1836\end{array}$ & 8 & 4 & 2 & 5 & 6 & 7 & 9 & 4 & 6 & 1 & 52 & 4,6 \\
\hline $\begin{array}{l}\text { Neohydatothrips gracilicornis } \\
\text { (Williams1916) }\end{array}$ & 1 & 0 & 1 & 0 & 0 & 0 & 1 & 0 & 0 & 0 & 3 & 0,3 \\
\hline $\begin{array}{l}\text { Odontothrips loti } \\
\text { (Haliday 1852) }\end{array}$ & 2 & 0 & 1 & 1 & 0 & 0 & 0 & 1 & 0 & 0 & 5 & 0,4 \\
\hline $\begin{array}{l}\text { Stenothrips graminum } \\
\text { Uzel } 1895\end{array}$ & 0 & 0 & 4 & 0 & 0 & 0 & 0 & 0 & 0 & 0 & 4 & 0,3 \\
\hline $\begin{array}{l}\text { Thrips atratus } \\
\text { Haliday } 1836\end{array}$ & 2 & 5 & 3 & 3 & 8 & 3 & 2 & 2 & 3 & 1 & 32 & 2,8 \\
\hline $\begin{array}{l}\text { T. flavus } \\
\text { Schrank } 1776\end{array}$ & 0 & 0 & 0 & 0 & 0 & 0 & 0 & 0 & 0 & 1 & 1 & 0,1 \\
\hline $\begin{array}{l}\text { T. fuscipennis } \\
\text { Haliday } 1836\end{array}$ & 31 & 34 & 17 & 27 & 20 & 30 & 28 & 29 & 27 & 27 & 270 & 23,7 \\
\hline $\begin{array}{l}\text { T. major } \\
\text { Uzel } 1895\end{array}$ & 0 & 0 & 0 & 0 & 0 & 0 & 0 & 1 & 0 & 0 & 1 & 0,1 \\
\hline $\begin{array}{l}\text { T. physaphus } \\
\text { Linneus } 1761\end{array}$ & 0 & 0 & 0 & 1 & 0 & 0 & 0 & 0 & 0 & 0 & 1 & 0,1 \\
\hline $\begin{array}{l}\text { T. tabaci } \\
\text { Lindeman } 1889\end{array}$ & 43 & 71 & 46 & 53 & 65 & 67 & 46 & 58 & 51 & 44 & 544 & 47,7 \\
\hline $\begin{array}{l}\text { T. validus } \\
\text { Uzel } 1895\end{array}$ & 0 & 0 & 0 & 0 & 1 & 0 & 0 & 0 & 0 & 0 & 1 & 0,1 \\
\hline Suma - Total & 116 & 138 & 96 & 105 & 127 & 125 & 113 & 124 & 112 & 85 & 1141 & 100,0 \\
\hline
\end{tabular}


Tabela 2. Liczebność roślinożernych wciornastków (owady dorosłe, larwy) odłowionych z poletek odmianowych marchwi w latach 2011-2012

Table 2. The number of herbivorous thrips (adults, larvae) collected from plots of carrot cultivars in 2011-2012

\begin{tabular}{|c|c|c|c|c|}
\hline \multirow[b]{2}{*}{$\begin{array}{l}\text { Odmiana } \\
\text { Cultivar }\end{array}$} & \multicolumn{2}{|c|}{ Owady dorosłe - Adults } & \multicolumn{2}{|c|}{ Larwy - Larvae } \\
\hline & $\begin{array}{c}\text { liczba } \\
\text { number }\end{array}$ & $\begin{array}{c}\text { udział } \\
\text { share } \\
{[\%]}\end{array}$ & $\begin{array}{l}\text { liczba } \\
\text { number }\end{array}$ & $\begin{array}{c}\text { udział } \\
\text { share } \\
{[\%]}\end{array}$ \\
\hline Afro $F_{1}$ & 116 & 93,5 & 8 & 6,5 \\
\hline Deep Purple $F_{1}$ & 138 & 92,0 & 12 & 8,0 \\
\hline Kongo $\mathrm{F}_{1}$ & 105 & 89,7 & 12 & 10,3 \\
\hline Kazan $\mathrm{F}_{1}$ & 96 & 90,6 & 10 & 9,4 \\
\hline Napa $F_{1}$ & 127 & 89,4 & 15 & 10,6 \\
\hline Nipomo $F_{1}$ & 125 & 94,7 & 7 & 5,3 \\
\hline Rumba $F_{1}$ & 124 & 93,2 & 9 & 6,8 \\
\hline Samba $F_{1}$ & 113 & 95,0 & 6 & 5,0 \\
\hline Yellowstone $\mathrm{F}_{1}$ & 112 & 94,9 & 6 & 5,1 \\
\hline White Satin $F_{1}$ & 85 & 88,5 & 11 & 11,5 \\
\hline Suma - Total & 1141 & 92,3 & 96 & 7,7 \\
\hline
\end{tabular}

Tabela 3. Wpływ żerowania T. tabaci na plonowanie wybranych odmian marchwi - wyniki doświadczenia izolatorowego w 2012 roku Table 3. Influence of T. tabaci feeding on yielding of selected carrot cultivars - results of the insulator experiment in 2012

\begin{tabular}{|c|c|c|c|c|c|c|c|c|}
\hline \multirow{2}{*}{$\begin{array}{l}\text { Odmiana } \\
\text { Cultivar }\end{array}$} & \multirow{2}{*}{$\begin{array}{l}\text { Wariant } \\
\text { Variant }\end{array}$} & \multirow{2}{*}{$\begin{array}{c}\text { Liczba } \\
\text { korzeni } \\
\text { Number of } \\
\text { roots }\end{array}$} & \multicolumn{2}{|c|}{$\begin{array}{c}\text { Korzenie } \\
\text { handlowe } \\
\text { Marketable roots }\end{array}$} & \multirow{2}{*}{$\begin{array}{l}\text { Średnia długość } \\
\text { korzenia } \\
\text { Average length } \\
\text { of } 1 \mathrm{root} \\
{[\mathrm{cm}]}\end{array}$} & \multirow{2}{*}{$\begin{array}{c}\text { Obniżka* } \\
\text { długości } \\
\text { Reduction in } \\
\text { length } \\
{[\%]}\end{array}$} & \multirow{2}{*}{$\begin{array}{c}\text { Średnia masa } \\
\text { korzenia } \\
\text { Average } \\
\text { weight } \\
\text { of } 1 \text { root } \\
{[\mathrm{g}]}\end{array}$} & \multirow{2}{*}{$\begin{array}{c}\text { Obniżka* } \\
\text { masy } \\
\text { Reduction in } \\
\text { weight } \\
{[\%]}\end{array}$} \\
\hline & & & $\begin{array}{l}{[\mathrm{szt} .]} \\
{[\mathrm{pcs}]}\end{array}$ & {$[\%]$} & & & & \\
\hline Afro $F_{1}$ & $\begin{array}{l}\mathrm{K} \\
\mathrm{W}\end{array}$ & $\begin{array}{l}15 \\
15\end{array}$ & $\begin{array}{l}15 \\
10\end{array}$ & $\begin{array}{c}100,0 \\
66,7\end{array}$ & $\begin{array}{l}5,6 \mathrm{a} \\
4,8 \mathrm{~b}\end{array}$ & - & $\begin{array}{l}25,0 \mathrm{a} \\
20,0 \mathrm{~b}\end{array}$ & $\begin{array}{c}- \\
20,0\end{array}$ \\
\hline Deep Purple $F_{1}$ & $\begin{array}{l}\mathrm{K} \\
\mathrm{W}\end{array}$ & $\begin{array}{l}14 \\
15\end{array}$ & $\begin{array}{l}14 \\
12\end{array}$ & $\begin{array}{c}100,0 \\
80,0\end{array}$ & $\begin{array}{l}8,8 \mathrm{a} \\
8,2 \mathrm{a}\end{array}$ & $\begin{array}{c}- \\
6,8\end{array}$ & $\begin{array}{c}17,0 \mathrm{a} \\
9,5 \mathrm{~b}\end{array}$ & - \\
\hline Kazan $\mathrm{F}_{1}$ & $\begin{array}{l}\mathrm{K} \\
\mathrm{W}\end{array}$ & $\begin{array}{l}14 \\
13\end{array}$ & $\begin{array}{c}11 \\
9\end{array}$ & $\begin{array}{l}78,5 \\
69,2\end{array}$ & $\begin{array}{c}9,5 \mathrm{a} \\
10,7 \mathrm{a}\end{array}$ & $\begin{array}{c}- \\
(-12,6)\end{array}$ & $\begin{array}{l}39,3 \mathrm{a} \\
30,0 \mathrm{~b}\end{array}$ & $-\frac{-}{23,7}$ \\
\hline Kongo $\mathrm{F}_{1}$ & $\begin{array}{l}\mathrm{K} \\
\mathrm{W}\end{array}$ & $\begin{array}{l}14 \\
12 \\
\end{array}$ & $\begin{array}{c}10 \\
8\end{array}$ & $\begin{array}{l}71,4 \\
66,7\end{array}$ & $\begin{array}{r}7,0 \mathrm{a} \\
5,9 \mathrm{~b}\end{array}$ & $\begin{array}{c}- \\
15,7\end{array}$ & $\begin{array}{l}20,2 \mathrm{a} \\
18,8 \mathrm{a}\end{array}$ & $\begin{array}{c}- \\
6,9\end{array}$ \\
\hline Napa $F_{1}$ & $\begin{array}{l}\mathrm{K} \\
\mathrm{W}\end{array}$ & $\begin{array}{l}14 \\
15\end{array}$ & $\begin{array}{c}11 \\
8\end{array}$ & $\begin{array}{l}78,5 \\
53,3\end{array}$ & $\begin{array}{l}6,3 \mathrm{a} \\
6,7 \mathrm{a} \\
\end{array}$ & $\begin{array}{c}- \\
(-6,3)\end{array}$ & $\begin{array}{l}17,5 \mathrm{a} \\
18,0 \mathrm{a}\end{array}$ & $\begin{array}{c}- \\
(-2,9)\end{array}$ \\
\hline Nipomo $F_{1}$ & $\begin{array}{l}\mathrm{K} \\
\mathrm{W}\end{array}$ & $\begin{array}{l}15 \\
15\end{array}$ & $\begin{array}{c}12 \\
9\end{array}$ & $\begin{array}{l}80,0 \\
60,0\end{array}$ & $\begin{array}{l}7,0 \mathrm{a} \\
7,5 \mathrm{a}\end{array}$ & $\begin{array}{c}- \\
(-7,1)\end{array}$ & $\begin{array}{l}21,5 \mathrm{a} \\
19,0 \mathrm{a}\end{array}$ & - \\
\hline Samba $F_{1}$ & $\begin{array}{l}\mathrm{K} \\
\mathrm{W}\end{array}$ & $\begin{array}{l}15 \\
15\end{array}$ & $\begin{array}{l}12 \\
12\end{array}$ & $\begin{array}{l}80,0 \\
80,0\end{array}$ & $\begin{array}{l}7,8 \mathrm{a} \\
7,8 \mathrm{a}\end{array}$ & $\begin{array}{c}- \\
0,0\end{array}$ & $\begin{array}{l}34,4 \mathrm{a} \\
27,3 \mathrm{a}\end{array}$ & $\begin{array}{c}- \\
20,6\end{array}$ \\
\hline Rumba $F_{1}$ & $\begin{array}{l}\mathrm{K} \\
\mathrm{W}\end{array}$ & $\begin{array}{l}15 \\
15\end{array}$ & $\begin{array}{l}14 \\
15\end{array}$ & $\begin{array}{c}93,3 \\
100,0\end{array}$ & $\begin{array}{l}5,6 \mathrm{a} \\
5,3 \mathrm{a}\end{array}$ & $\begin{array}{c}- \\
5,3\end{array}$ & $\begin{array}{l}20,2 \mathrm{a} \\
21,0 \mathrm{a}\end{array}$ & $\begin{array}{c}- \\
(-3,9)\end{array}$ \\
\hline Yellowstone $F_{1}$ & $\begin{array}{l}\mathrm{K} \\
\mathrm{W}\end{array}$ & $\begin{array}{l}15 \\
15\end{array}$ & $\begin{array}{c}12 \\
8\end{array}$ & $\begin{array}{l}80,0 \\
50,0\end{array}$ & $\begin{array}{l}6,6 \mathrm{a} \\
6,6 \mathrm{a}\end{array}$ & $\begin{array}{c}- \\
0,0\end{array}$ & $\begin{array}{l}20,0 \mathrm{a} \\
15,0 \mathrm{a}\end{array}$ & $\begin{array}{c}- \\
25,0\end{array}$ \\
\hline White Satin $F_{1}$ & $\begin{array}{l}\mathrm{K} \\
\mathrm{W}\end{array}$ & $\begin{array}{l}13 \\
14\end{array}$ & $\begin{array}{l}13 \\
10\end{array}$ & $\begin{array}{c}100,0 \\
71,4\end{array}$ & $\begin{array}{l}8,5 \mathrm{a} \\
8,3 \mathrm{a}\end{array}$ & - & $\begin{array}{l}21,7 \mathrm{a} \\
19,3 \mathrm{a}\end{array}$ & $\begin{array}{c}- \\
11,1\end{array}$ \\
\hline
\end{tabular}

$\mathrm{K}$ - rośliny niezasiedlone (kontrola) - not infested plants (control)

$\mathrm{W}$ - rośliny zasiedlone przez wciornastki - plants infested with thrips

*wartości ujemne w nawiasach oznaczają zwiększenie długości lub masy korzeni - negative values in brackets indicates the increase in length or in weight of roots

Wartości średnie oznaczone w kolumnach tą samą literą nie różnią się istotnie między sobą (5\%) według testu t-Studenta

Average values in columns marked with the same letter do not differ at $5 \%$ level of significance (t-Student's test) 
Tabela 4. Wpływ żerowania T. tabaci na zawartość cukrów i karotenoidów w korzeniach wybranych odmian marchwi - wyniki doświadczenia izolatorowego w 2012 roku

Table 4. Influence of T. tabaci feeding on the content of sugars and carotenoids in roots of selected carrot cultivars - results of the insulator experiment in 2012

\begin{tabular}{|c|c|c|c|c|c|c|c|c|c|}
\hline \multirow{3}{*}{$\begin{array}{l}\text { Odmiana } \\
\text { Cultivar }\end{array}$} & \multicolumn{9}{|c|}{$\begin{array}{c}\text { Zawartość składnika }[\mathrm{mg} / 100 \mathrm{~g} \text { świeżej masy korzeni] oraz różnica - spadek, wzrost } \\
\text { Content of the component }[\mathrm{mg} / 100 \mathrm{~g} \text { fresh root weight] and difference - decrease, increase } \\
{[\%]}\end{array}$} \\
\hline & \multicolumn{2}{|c|}{$\begin{array}{l}\text { cukry } \\
\text { rozpuszczalne } \\
\text { soluble sugars }\end{array}$} & \multirow{2}{*}{$\begin{array}{c}\text { spadek } \\
\text { (wzrost) } \\
\text { decrease } \\
\text { (increase) } \\
{[\%]}\end{array}$} & \multicolumn{2}{|c|}{$\begin{array}{l}\text { sacharoza } \\
\text { sucrose }\end{array}$} & \multirow{2}{*}{$\begin{array}{c}\text { spadek } \\
\text { (wzrost) } \\
\text { decrease } \\
\text { (increase) } \\
{[\%]}\end{array}$} & \multicolumn{2}{|c|}{$\begin{array}{l}\text { suma karotenoidów } \\
\text { total carotenoids }\end{array}$} & \multirow{2}{*}{$\begin{array}{c}\text { spadek } \\
\text { (wzrost) } \\
\text { decrease } \\
\text { (increase) } \\
{[\%]}\end{array}$} \\
\hline & $\mathrm{K}$ & W & & K & W & & $\mathrm{K}$ & W & \\
\hline Afro $F_{1}$ & 16,9 & 17,6 & $(4,1)$ & 10,4 & 14,7 & $(41,3)^{*}$ & 8,91 & 10,98 & $(23,2)$ \\
\hline Deep Purple $F_{1}$ & 9,2 & 12,4 & $(34,8)$ & 6,6 & 9,6 & $(45,4)^{*}$ & 0,52 & 0,65 & $(25,0)$ \\
\hline Kazan $F_{1}$ & 13,7 & 40,4 & $(194,9)^{*}$ & 12,0 & 31,4 & $(161,7)^{*}$ & 17,91 & 8,53 & $52,4^{*}$ \\
\hline Kongo $\mathrm{F}_{1}$ & 13,1 & 22,7 & $(73,3)^{*}$ & 9,5 & 14,1 & $(48,4)^{*}$ & 13,07 & 7,99 & $38,9 *$ \\
\hline Napa $F_{1}$ & 17,8 & 17,7 & 0,6 & 11,0 & 12,9 & $(17,3)$ & 9,21 & 6,81 & 26,1 \\
\hline Nipomo $F_{1}$ & 17,9 & 21,0 & $(17,3)$ & 13,2 & 14,9 & $(12,9)$ & 12,65 & 10,57 & 16,4 \\
\hline Samba $F_{1}$ & 21,8 & 33,2 & $(52,3)^{*}$ & 17,0 & 23,0 & $(35,3)^{*}$ & 11,65 & 11,10 & 4,7 \\
\hline Rumba $F_{1}$ & 15,5 & 20,4 & $(31,6)^{*}$ & 12,2 & 13,7 & $(12,3)$ & 8,66 & 6,89 & 20,4 \\
\hline Yellowstone $\mathrm{F}_{1}$ & 12,3 & 17,5 & $(42,3)^{*}$ & 9,7 & 11,8 & $(21,6)$ & 0,56 & 0,65 & $(16,1)$ \\
\hline White Satin $F_{1}$ & 16,7 & 13,9 & 16,8 & 11,2 & 8,1 & $27,7^{*}$ & 0,20 & 0,12 & 40,00 \\
\hline
\end{tabular}

$\mathrm{K}$ - rośliny niezasiedlone (kontrola) - not infested plants (control)

$\mathrm{W}$ - rośliny zasiedlone przez wciornastki - plants infested with thrips

*różnica istotna $(\mathrm{p}=0,05)$ - significant difference at $\mathrm{p}=0.05$

Spośród odłowionych gatunków tylko $T$. tabaci jest groźnym szkodnikiem wielu gatunków warzyw. Występowanie wciornastka tytoniowca na marchwi odnotował Sakimura (1938), z kolei Zawirska (1994) wymienia marchew, jako jedną $\mathrm{z}$ roślin żywicielskich dla tego gatunku wciornastka.

W doświadczeniu poletkowym pod izolatorami (rok 2012) stwierdzono różny (dla poszczególnych odmian) wpływ żerowania $T$. tabaci na plonowanie marchwi (tab. 3). W izolatorach, na żerowanie wciornastków, rośliny większości odmian reagowały spadkiem procentowego udziału korzeni handlowych w łącznej ich liczbie. Takiej reakcji nie wykazały 2 odmiany: Rumba $F_{1}$ i Samba $F_{1}$. Najsilniej na żerowanie wciornastka tytoniowca reagowała odmiana Afro $\mathrm{F}_{1}$; obserwowano istotne i dość wysokie spadki w masie (o 20\%) i wielkości korzeni (o 14\%) oraz największą (ponad 33\%) redukcję liczby korzeni handlowych. Istotne zmniejszenie wielkości korzeni (długość w cm) stwierdzono także (w izolatorach $\mathrm{z}$ T. tabaci) na odmianie Kongo $\mathrm{F}_{1}$. Silny negatywny wpływ żerowania wciornastków na masę korzeni wykazano dla 2 odmian (Kazan $F_{1}$ i Deep Purple $F_{1}$ ) - spadki $\mathrm{w}$ masie korzeni wynosiły odpowiednio: 23,7 oraz $44,1 \%$ (tab. 3).

W korzeniach marchwi, u roślin zasiedlonych przez T. tabaci, obserwowano zmiany $\mathrm{w}$ zawartości cukrów i sumy karotenoidów, w stosunku do roślin niezasiedlonych (izolatory kontrolne) (tab. 4). U większości odmian stwierdzono wzrost poziomu cukrów rozpuszczalnych i sacharozy w efekcie żerowania wciornastków; odmienną reakcję, tj. spadek zawartości cukrów, jak również sumy karotenoidów, wykazano w białych korzeniach odmiany White Satin $F_{1}$. Ta silna reakcja roślin marchwi odmiany White Satin $F_{1}$ na żerowanie najbardziej szkodliwego gatunku $T$. tabaci i jednocześnie mała ich atrakcyjność do zasiedlania przez wciornastki, wskazuje na niską wytrzymałość (tolerancję) tej odmiany marchwi wobec roślinożernych Thysanoptera.

Najsilniejszy wzrost poziomu cukrów rozpuszczalnych i sacharozy (o ponad 100\%) w korzeniach roślin zasiedlonych przez T. tabaci, odnotowano na marchwi odmiany Kazan $F_{1}$. Nieco mniejszy wzrost stężenia sacharozy zaobserwowano u 3 innych odmian: Kongo $F_{1}$, Deep Purple $\mathrm{F}_{1}$ i Afro $\mathrm{F}_{1}$. Wykazane (u tych 4 odmian marchwi) istotne $\mathrm{i}$ wysokie spadki w masie $\mathrm{i} /$ lub wielkości korzeni oraz silny wzrost poziomu sacharozy w korzeniach moga wskazywać na zmiany w metabolizmie roślin i zakłócenia $\mathrm{w}$ transporcie asymilatów z liści do korzeni - będące efektem żerowania wciornastków. W dostępnej literaturze, jedynie Muthuswami i wsp. (2010) oraz Mahadeva (2011) badali wpływ żerowania wciornastków na zawartość w roślinach cukrów i stwierdzili ich spadek w liściach morwy.

W izolatorach z T. tabaci (wariant I), u 7 odmian marchwi, stwierdzono spadek zawartości sumy karotenoidów w korzeniach (tab. 4). Z grupy odmian posiadających korzenie o zabarwieniu pomarańczowym, największym spadkiem zawartości karotenoidów zareagowały 
dwie odmiany (o najwyższym poziomie tych barwników w korzeniach): Kazan $F_{1}$ (spadek o $52,4 \%$ ) i Kongo $F_{1}$ (spadek o 38,9\%). Rośliny marchwi odmiany Deep Purple $F_{1}$ (o korzeniach purpurowych) i Yellowstone $F_{1}$ (o korzeniach żółtych) - charakteryzujące się bardzo niską zawartością karotenoidów w korzeniach, reagowały na żerowanie $T$. tabaci nieistotnym wzrostem stężenia tych składników. Podobną reakcję obserwowano na marchwi odmiany Afro $F_{1}$ (o pomarańczowym zabarwieniu korzeni); tutaj wykazano także wysokie i istotne spadki w masie i wielkości korzeni. Odmienną reakcję, tj. wysoki (choć nieistotny) spadek zawartości sumy karotenoidów (o 40\%), stwierdzono w białych korzeniach marchwi odmiany White Satin $\mathrm{F}_{1}$ (o najniższym poziomie tego barwnika - $20 \mathrm{mg} / 100 \mathrm{~g}$ świeżej masy korzeni). Zmniejszenie zawartości karotenoidów w liściach $H y$ pericum sampsonii Hance, wskutek żerowania T. tabaci, obserwowali Dai i wsp. (2009). Badania Mahadeva (2011) potwierdziły ujemny wpływ żerowania wciornastków na zawartość tych barwników w liściach morwy. Zaobserwowany u 3 odmian marchwi (Afro $F_{1}$, Deep Purple $\mathrm{F}_{1}$, Yellowstone $\mathrm{F}_{1}$ ) wzrost poziomu karotenoidów $\mathrm{z}$ jednoczesnym spadkiem masy i wielkości korzeni, może wskazywać na przyspieszenie procesu starzenia $\mathrm{u}$ roślin zasiedlonych przez wciornastki. Podobne zjawiska są opisywane przy żerowaniu mszyc (Burd 2002; Łuczak i wsp. 2012). Otrzymane wyniki stanowią ważną informację dla plantatorów i hodowców marchwi. Wskazują one, że rośliny nowych mieszańcowych odmian są w niejednakowym stopniu zasiedlane przez dominujące gatunki wciornastków i reagują na ich żerowanie różnym procentowym spadkiem plonu handlowego korzeni. Wykorzystanie do uprawy odmian słabo zasiedlanych lub wykazujących tolerancję wobec najgroźniejszego wciornastka $T$. tabaci jest konieczne $\mathrm{w}$ integrowanej ochronie roślin i integrowanej produkcji marchwi.

\section{Wnioski / Conclusions}

1. Wśród 15 fitofagicznych gatunków wciornastków stwierdzonych na roślinach marchwi jadalnej, najliczniej reprezentowane były: T. tabaci $(47,7 \%)$, T. fuscipennis $(23,7 \%)$ i $F$. intonsa $(7,6 \%)$. Zasiedlały one wszystkie testowane odmiany marchwi, ale w niejednakowym stopniu.

2. Najwięcej wciornastków (150 - łącznie owady dorosłe i larwy) odłowiono $\mathrm{z}$ roślin marchwi odmiany Deep Purple $\mathrm{F}_{1}$ - o purpurowym zabarwieniu korzeni i ciemnym (przebarwiającym się na czerwono i fioletowo) listowiu; liczba wciornastków była najmniejsza na marchwi odmiany White Satin $\mathrm{F}_{1}-\mathrm{o}$ białych korzeniach i bladozielonych liściach.

3. Rośliny marchwi izolowane na poletkach i zasiedlone jednakową liczbą samic $T$. tabaci reagowały prawie zawsze spadkiem ilościowego plonu (redukcja liczby i \% korzeni handlowych oraz zmniejszenie ich długości i masy).

4. W korzeniach marchwi większości odmian zasiedlonych przez $T$. tabaci stwierdzono wzrost zawartości cukrów rozpuszczalnych i sacharozy; odmienną reakcję, tj. spadek zawartości cukrów wykazano tylko $\mathrm{u}$ marchwi odmiany White Satin $\mathrm{F}_{1}$ (o białych korzeniach).

5. W efekcie żerowania wciornastka tytoniowca u 7 odmian marchwi następował spadek zawartości sumy karotenoidów w korzeniach (od 5 do 50\%). Wzrost poziomu tych barwników o 16, 23 i 25\% odnotowano w korzeniach 3 odmian: Yellowstone $F_{1}$, Afro $F_{1}$ i Deep Purple $F_{1}$.

6. Konieczne są dalsze szczegółowe badania nad skutkami żerowania Thysanoptera na roślinach marchwi i określeniem progów szkodliwości w odniesieniu do uprawianych odmian.

\section{Literatura / References}

Alford D.V. 2002. Pests of Ornamental Trees, Shrubs and Flowers. Manson, London, 449 pp.

Burd J. 2002. Physiological modification of the host feeding site by cereal aphids (Homoptera: Aphididae). J. Econ. Entomol. 95 (2): 463-468.

Dai Y., Shao M., Hannaway D., Wang L., Liang J., Hu L., Lu H. 2009. Effect of Thrips tabaci on anatomical features, photosynthetic characteristics and chlorophyll fluorescence of Hypericum sampsonii leaves. Crop Prot. 28 (4): 327-332.

Legutowska H. 1997. Thrips on cabbage crops in Poland. Biul. Warzyw. 47: 55-62.

Legutowska H., Kucharczyk H. 2000. A comparison of the number of thrips on leek cultivated in monocrop and intercropping with high and low-growing white clover. Ann. Warsow Agric. Univ. - SGGW, Hortic. Land. Archit. 21: 3-8.

Legutowska H., Theunissen J. 2003. Thrips species in leek and their undersown intercrops. IOBC/WPRS Bull. 26 (3): $177-182$.

Łuczak I., Świderski A., Gaborska M., Mech-Nowak A. 2012. Występowanie i szkodliwość mszycy burakowej (Aphis fabae Scop.) w uprawie marchwi. [Occurrence and harmfulness of black bean aphid (Aphis fabae Scop.) in carrot crops]. Prog. Plant Prot./Post. Ochr. Roślin 52 (2): 235-239.

Mahadeva A. 2011. Influence of thrips (Pseudodendothrips mori) infestation on the biochemical constituens and photosyntethic pigments of mulberry (Morus ssp.) leaves. Int. J. Plant, Anim. Enviromen. Sci. 1 (3): 57-63.

Muthuswami M., Subramanian S., Krishnan R., Thangamelor A., Indumathi P. 2010. Quantitative and qualitative damage caused in mulberry varieties due to infestation of thrips Pseudodentrothrips mori Niwa. Karnataka J. Agric. Sci. 23 (1): 146-148.

Nath N., Singh M.P. 1965. Mechanism of the oxidation of reducing sugars (hexoses) by hexacyanoferrate (III) in alkaline medium and Lobry de Bruyn transformation. J. Phys. Chem. 69: 2038-2043.

Pobożniak M. 2005. Thrips species on white cabbage. Electr. J. Pol. Agric. Univ. Hortic. 8 (4), p. 60. http://www.ejpau.media.pl/ volume8/issue4/art-60.html [Accessed: 19.12.2005]. 
Pobożniak M. 2009. Wstępna ocena podatności odmian grochu na zasiedlenie i żerowanie wciornastków. [Preliminary estimation of susceptibility of various pea cultivars (Pisum sativum L.) to thrips (Thysanoptera) infestation and feeding]. Prog. Plant Prot./Post. Ochr. Roślin 49 (3): 1215-1219.

Pobożniak M. 2011. The occurrence of thrips (Thysanoptera) on food legumes (Fabaceae). J. Plant Dis. Prot. 118: $185-193$.

Pobożniak M., Gaborska M. 2010. Wstępna analiza gatunków wciornastków zasiedlających groch. [Preliminary analysis of thrips species on pea]. Prog. Plant Prot./Post. Ochr. Roślin 50 (4): 1729-1732.

Pobożniak M., Wiech K. 2004. Występowanie Thrips tabaci Lindemann (Thysanoptera, Thripidae) na późnych odmianach kapusty białej. [The occurrence of Thrips tabaci Lindeman (Thysanoptera, Thripidae) on late cultivars of white cabbage]. Nowości Warzywnicze/Veg. Crop News 39: 149-155.

Richter E., Hommes M., Krauthausen J.H. 1999. Investigations on the supervised control of Thrips tabaci in leek and onion crops. IOBC/WPRS Bull. 22: 61-72.

Sakimura K. 1938. Thysanoptera of Kauai with notes of the incidence of yellow spot on wild host plants. Proc. Hawaiian Entomol. Soc. 10 (1): 167-173.

Samotus B., Tuz J., Doerre E. 1993. Evaluation of Blue Value in different plant materials as a tool for rapid starch determination. Acta Soc. Bot. Pol. 62: 137-141.

Shelton A.M., Hoy C.W., Dickson M.H., Barnard J. 1988. Analysis of resistance in cabbage varieties to damage by Lepidoptera and Thysanoptera. J. Econ. Entomol. 81 (2): 634-640.

Strassen zur R. 2003. Die terebranten Thysanopteren Europas. Goecke \& Evers, Keltern, 277 pp.

Szwejda J. 2002. Nowe zagrożenia roślin warzywnych stwarzane przez entomofaunę fitofagiczną i metody ich ochrony. Zesz. Nauk. AR Kraków 387: 271-275.

Świderski A., Kostecka-Gugała A. 2009. Związki wtórne. s. 125-148. W: „Ćwiczenia z biochemii” (H. Kołoczek, red.). Wydanie 2 poprawione i uzupełnione. Wyd. Uniwersytetu Rolniczego w Krakowie, 148 ss.

Zawirska I. 1994. Wciornastki (Thysanoptera). s. 145-174. W: „Diagnostyka szkodników roślin i ich wrogów naturalnych" (M.W. Kozłowski, J. Boczek, red.). Wyd. SGGW, Warszawa, 328 ss. 